\title{
Introduction: Hybrid Security Governance in Africa
}

\author{
Niagalé Bagayoko
}

\begin{abstract}
Security Sector Reform (SSR) programmes have not sufficiently acknowledged the fact that in Africa, security governance is based on a complex amalgam of statutory and non-statutory actors and institutions which do form the security sector. SSR processes are more often than not focused on structural and formal institutional arrangements of the state and are generally seen as a purely technico-institutional reform, based on techniques of organisational engineering and principles of institutional design. Consequently, security reform processes, most of the time promoted or supported by external donors, tend to be driven by an administrative view of the state which emphasises its legal structure whilst glossing over its political and social character. Today, there is a dire need to take a critical stance on the relationships between the various systems, actors and beneficiaries involved in the security sector on the African continent. This introductive article proposes to refer to the analytic model of 'hybridity' to grasp the current realities and the prospects of the security sector in African countries.
\end{abstract}

The rise of the security sector reform (SSR) concept has recognised and renewed the importance of security forces in democratisation processes and paved the way for a civilianisation of security provision in African states (OECD 2007). Security reform has increasingly been seen by international actors as a major area of, and been presented as, a central matter of democracy with security forces being considered as meant to be dedicated to promoting and defending the rule of law and, ultimately, the degree to which political and human rights can be enjoyed equally by all citizens. Transforming such forces into rights-respecting services that provide protection both to the state and to citizens has been one of the most complex challenges, particularly in post-conflict situations where security forces have often perpetuated serious human rights violations.

Since the last decade, many African governments have introduced security restructuring programmes, frequently under pressure from the international community. However, such policies have in most cases encountered mitigated or limited success when they have not completely failed. In fact, there is a missing link in SSR policies: the specific circumstances of African states have hardly been recognised. SSR reform programmes as generally promoted by international actors have not sufficiently acknowledged the fact that in Africa, security governance is based on a complex amalgam of statutory and non-statutory actors and institutions which form the security sector. Indeed, SSR processes are more often than not focused on structural and formal institutional arrangements of the state. International donors often tend to view SSR as a purely technicoinstitutional reform, using techniques of organisational engineering and principles of institutional design. Too often, security reform processes supported by external donors tend to be driven by an administrative view of the state which emphasises its legal structure whilst glossing over its political and social character. Consequently, international actors too often recommend applying technocratic practices geared at building security capabilities meant to deliver Western-style policing.

Whilst promoting a legal-rational approach to SSR, most external actors tend not to be aware of, minimise or in some cases ignore the importance of informal norms and processes which also characterise security governance in

IDS Bulletin Volume 43 Number 4 July 2012 @ 2012 The Author. IDS Bulletin (? 2012 Institute of Development Studies Published by Blackwell Publishing Ltd, 9600 Garsington Road, Oxford OX4 2DQ, UK and 350 Main Street, Malden, MA 02148, USA 
Africa. Yet, there is a dire need today to take a critical stance on the relationships between the various systems, actors and beneficiaries involved in the security sector on the African continent.

This IDS Bulletin precisely aims to focus on both formal and informal governance mechanisms ${ }^{1}$ which do characterise African security systems. Most of the contributions identify informal networks and processes which, alongside legally established structures, influence decisionmaking processes as well as policy implementation: they provide an analysis of the interactions between such informal networks and processes on the one hand, and formal ones at the local, national or international level.

The articles gathered here are based on desk and field research, conducted within the framework of the 'Global Uncertainties: Security in an Africa of Networked, Multilevel Governance's programme, which has been investigating the ways in which African security governance is reshaped by the interactions of the heterogeneous norms, standards and procedures promoted by local, national and international actors. This programme has been built on the observation that security governance in Africa is multilevelled and networked - from the village to the international organisation, and well beyond what is specified in formal government structures. The focus has not only been on the ways in which key conflict-management institutions evolve themselves but also on the changing ways in which the networks they are embedded in actually operate as they try to rebuild governance in security-challenged societies.

The articles in this IDS Bulletin specifically address the current state of the security sector in African countries, referring to the analytic models of 'hybridity' to grasp the current realities and the prospects for change in security-related policies.

\section{Hybrid security orders}

A number of scholars have proposed to analyse and understand political orders in the global South using the concept of 'hybridity'. This concept is generally promoted to offer an alternative to a concept such as 'fragile' states but also - and more interestingly as far as the topic addressed in this issue is concerned - to the legal-rational approach which underlies most of the public policies promoted by international donors and policymakers, particularly in peace building processes.

Focusing primarily on state formation in South Pacific and Southeast Asian countries like Papua New Guinea, the Solomon Islands, Vanuatu and East Timor, Volker Boege has thoroughly studied the interpenetrations of different social spheres and the subsequent interactions between the formal state apparatus on the one hand, and informal institutions on the other hand, leading to the emergence of hybrid political orders. In most developing countries, 'These hybrid orders are characterized by a plurality of overlapping rule systems which has a profound effect on politics and policies in these societies' (Institute for Development and Peace 2008). Boege's analysis refers to the Weberian distinction between three different kinds of legitimacy, based on:

- firstly, legal authority which refers to rational grounds - 'resting on a belief in the "legality", of patterns of normative rules and the right of those elevated to authority under such rules to issue commands;

- secondly, traditional authority referring to traditional grounds - resting on an established belief in the sanctity of immemorial traditions and the legitimacy of the status of those exercising authority under them;

- thirdly, charismatic authority referring to charismatic grounds - resting on devotion to the specific and exceptional sanctity, heroism or exemplary character of an individual person, and of the normative patterns or order revealed or ordained by him.

Boege considers that Weberian legal-rational legitimacy has been overemphasised in Southern countries, and suggests we also need to explore the significance of different types and sources of legitimacy, including traditional and charismatic as well as hybrid forms of legitimacy. He focuses on non-Western local approaches to conflict transformation (non-state customary institutions, mechanisms and actors) and on the interface of local and liberal Western approaches to peace building (Boege 2006; Boege et al. 2008, 2009).

Similarly, Tobias Debiel and Daniel Lambach have also investigated the concept of 'hybrid political orders', which they view as a regular 
feature of social and political life in many Southern countries (Debiel and Lambach 2009). As they state on their research programme page, Hybrid Political Orders in Fragile Environments, 'Far from being cultural remnants as orthodox statebuilding approaches portray them, hybrid political orders are vibrant mechanisms of governance'. Their research programme analyses the interaction between the hybrid institutions and donor actors in development cooperation.

At present, very little is known about these hybrid orders, which can hardly be captured in all their dimensions. As stated by the Governance and Social Development Resource Centre (GSDRG),

Donors have tended to focus on formal political institutions and structures. Although these are important, it is essential to recognize that much political activity takes place according to informal norms and systems in developing countries. Whilst formal political systems are generally publicly announced, for example in laws, regulations and codes, informal systems are embedded in socio-cultural institutions, norms and standards. (...) The relative influence of formal and informal political systems in local and national politics is a critical debate. The literature has tended to presume a clear dichotomy between formal and informal, traditional and modern, and democratic and non-democratic political systems. But in reality, these distinctions are not so clear, and formal and informal systems overlap and interrelate' (Scott and Mcloughlin 2012: 11).

Focusing specifically on the security sector enables one to get a sense of the interactions at stake and to answer the following questions:

- How do hybrid political orders influence security reform processes?

- How do hybrid orders relate to external actors?

To answer those questions, it is relevant to refer to a neo-institutionalism theoretical framework, which defines institutions as the set of formal and informal rules, customs, habits and routines by which decisions are made concerning the distribution of power and the organisation of a given society. As stated by Vivien A. Schmidt (2006: 3), whilst rational choice institutionalism focuses on rational actors pursuing their interests and following their preferences within political institutions, defined as structures of incentives, according to a 'logic of calculation' [h] istorical institutionalism concentrates instead on the history of political institutions and their constituent parts, which have their origins in the (often unintended) outcomes of purposeful choices and historically unique initial conditions, and which develop over time following a 'logic of path-dependence'. Sociological institutionalism sees political institutions as socially constituted and culturally framed, with political agents acting according to a 'logic of appropriateness' that follows from culturally-specific rules and norms.

As stated by March and Olsen (2004), the 'logic of appropriateness' is a perspective that sees human action as driven by rules of appropriate behaviour, organised into institutions: rules can be defined as 'routines, procedures, conventions, roles, strategies, organizational forms, and technologies around which political activity is constructed' but they also refer to the 'beliefs, paradigms, codes, cultures, and knowledge that surround, support, elaborate, and contradict those roles and routines' (March and Olsen 1989: 17).

Both historical and sociological institutionalism believe that decision-making processes are not exclusively nested in formal institutions which can be defined as formal structures corresponding to the institutional, organisational and bureaucratic structures derived from the constitutional architecture which was set up (and perpetuated) after Independence, such as constitutions, laws, decrees, as well as legally-established administrative structures such as ministries, legislature, rule of law institutions, political parties, and so on (Chabal 2007). According to historical and sociological institutionalism, a wider variety of institutions operate alongside or within formal political institutions and are at play in decision-making processes and public policies, most of which are informal in essence. As shown by Hyden, 'sociological and historical institutionalists consider that institutions have a life of their own shaping agency through socialization over time. Informal institutions, however, do not preclude a form of rationality' (2006: 5). Informal systems are based on implicit rules and unwritten understandings. They reflect 


\begin{tabular}{lll}
\hline \multicolumn{2}{l}{ Table 1 Comparison of formal and informal institutions } \\
\hline Variable & Formal institutions & Informal institutions \\
\hline Type of exchange & Impersonal & Face-to-face \\
Approach to rules & Rule of law & Rules in use \\
Character of rules & Written & Unwritten \\
Nature of exchange & Contractual & Non-contractual \\
Time schedule & Specified & Non-specified \\
Actor premise & Organizational goal adherence & Shared expectations \\
Implications of agreement & Precise compliance & Ambiguous execution \\
Transparency & Potentially open to scrutiny & Closed and confidential \\
Conflict resolution & Third party body & Self-enforcement \\
\hline
\end{tabular}

Source Hyden (2006).

sociocultural routines and norms as well as underlying patterns of interactions among socioeconomic classes (for instance caste systems) and communities (different ethnic groups). According to Hyden (2006: 10), the essence of these informal institutions can be summarised in the following points: (1) actors share a common set of expectations, (2) they rely on simple forms of reciprocity, (3) rules are unwritten but understood by each actor, (4) exchanges are noncontractual and non-specified in terms of time, (5) they are being implemented confidentially and with no particular attention to detailed objectives or methods, and (6) they rely on selfenforcement in case of a breach of the perceived agreement.

How informal institutions differ from formal ones is summarised in Table 1.

Such a comparison is relevant to the kind of analyses developed in this issue, even if they differ from it on an important point: the different articles do consider that exchanges in African polities are definitely contractual, in the sense that they persist across time and have a strong element of obligation. They are in accordance with Eric Scheye in considering that 'The relationships between the state and nonstate networks is between polities, one that ebbs and flows based upon the circulation and dynamics of balances of power. Furthermore, the relationships between and among the differing layers of authority is an integral part of the social contract that establishes the state' (Scheye
2009: 7). Social exchanges embedded in informal institutions are also contractual in essence but it is the basis of the contract which differs. ${ }^{3}$

The different articles of this IDS Bulletin insist on the mutual processes and on the continuing transformation at stake, assuming that the states and the informal networks are not mutually exclusive. On the contrary, in Africa, the state and the informal networks have to be seen as embedded one into the other.

\section{Informalisation, deviation and instrumentalisation of legally-established security structures}

'While government institutions are important, the state qualities of governance - that is, being able to define and enforce collectively binding decisions on members of society - are not exclusively nested in these institutions. A wider variety of institutions are at play in this enterprise' (Lund 2006: 685). Most of the articles of this IDS Bulletin specifically focus on customary and social practices which are embedded into state structures and decision-making processes. Indeed, studying security reform processes shows that within the institutional frameworks legally established, informal societal institutions and practices follow their own logic and rules deviating the state from its Weberian ideal-type. State structures - which most of the time have been inspired by the legal-rational form of the Western state - are informed and in fact modified by the incorporation of indigenous norms and social practices. 
Their approach is inspired by the historical institutionalism, ${ }^{4}$ which puts the stress on 'path dependencies': to understand current security governance in African countries, the articles show how useful it can be to examine the historical trajectory of the police sector. They emphasise the importance of the colonial legacy on the (authoritarian) way in which the security sector has been governed since Independence. Indeed, in many African countries, the nature and character of the security forces have been deeply affected by the autocratic nature of the colonial state, as also shown by Anderson and Killingray (1991 and 1992), even if such colonial forces can be remembered in the popular memory as highly respected and professional ones. Beyond the importance of the colonial heritage, some articles stress the importance of the legacy of the politicisation mechanisms which were introduced after Independence, thus challenging the neutrality of the security forces and creating imbalances in its political allegiance as well as in recruitment processes and management procedures.

Sociological institutionalism is also implicitly referred to by some of the contributors, who demonstrate that far from exclusively amounting to formal institutional frameworks, institutions generate an interpersonal trust that is more immediate and exclusively reliant on unwritten rules in use. 'Informal institutions determine the use of power and thus the distribution of goods is politicised to favour those who are connected to the government through ties of dependence with political leaders' (Hyden 2008: 32). The different contributions refer to the ways in which clientelistic and patronage networks are penetrating the governance structures of the formal state in order to promote their own interests, often at the expense of public interests. Our case studies show that Weberian-rationalist institutions are used as resources to strengthen solidarities with, and networks affiliated to, the ruling elite. They demonstrate that the constitutional and legal resources offered by the formal framework of the African state are used by political leaders to shape political decisions on the basis of mutual gains with the members of their ethnic and family networks. It is in this way that the analyses developed in this issue slightly differ from most neo-patrimonialist theories. Whilst such approaches generally consider that Western-style formal institutions are weak in essence and are to a large extent in contradiction with the informal systems of power, all the articles demonstrate that, on the contrary, the informal systems of power are in fact complementary to the legally-established frameworks: both formal and informal institutions are seen as functional by the politicoadministrative elites and are mobilised in order to legitimise their power and authority, particularly in the security sector. Some of them insist on the fact that presidential leadership in the security sector - as acknowledged and promoted by the Constitution - is structured around particularistic, personalised, networks, which are embedded into formal institutions and legislations. Those articles also insist on the processes of appropriation of state institutions and on the penetration of formal state structures by some groups, stressing the efforts made by ruling elites to adjust to and manipulate the legal-rational arrangements to make them congruent with their interest. So, the relationship between formal and informal institutions is mutually reinforcing and in fact, there is an integration of the formal and informal spheres. Brinkerhoff and Goldsmith (2002) had already shown that informal systems of powers (such as patrimonialism and clientelism) and formal political systems (including processes such as liberalisation, democratisation, decentralisation and civil service reform) are not isolated from each other or society at large: according to them, informal systems are based on existing patterns of power, and they can adapt to the development of formal institutions and coexist with them. As advocated by Brinkerhoff and Goldsmith (2002: 35), there is a need for a 'more detailed understanding of the embeddedness of social relations and state-society interaction patterns' and for a 'recognition that there are functional aspects to these relations and patterns'. That is what this IDS Bulletin intends to provide.

The legal framework is not the only one at stake: formal procedures are also subject to deviation. For instance, most of the security reform programmes aim to ensure fair, balanced and equitable recruitment, putting the focus on the transformation of the composition of the institution with regards to its social, ethnic, regional and gender composition, and its human resource practices, in order to promote the emergence of a less-corrupted and more professional body of security officers. However, 
criteria for recruitment and promotion within the security forces are still characterised by a high degree of opaqueness, and privileges and promotion are more often than not allocated on a subjective basis: even in countries where there is no exclusive ethnic-based policy, ethnic affiliations and regional ties still do matter more than professionalism and in the absence of formalised institutional contracts, citizens rely on informal social contracts to progress in life.

It is also worth noting that formal and informal governance systems are not necessarily feeding each other in a democratic way: the formal institutional framework modelled on Western institutions is not automatically conducive to democratic security governance and, for instance, the institutional, organisational and bureaucratic structures which derive from the constitutional architecture set up after Independence and inherited (particularly from the French model) can easily pave the way to undemocratic practices. Furthermore, formal institutions of democratic security governance can fuel the informal practices of exploitation ${ }^{5}$ in the sense that formal, legal structures are often used by political elites as a means of informal exploitation of the less educated, who generally do not have the knowledge or resources to employ the formal legal structures to defend themselves. Consequently, formal legality becomes a resource employed only by the elites to advance their own interests. Under such conditions, security sector reform - which is clearly an attempt at reforming and transforming governance and power distribution in security systems by democratising them - can be a highly controversial endeavour likely to involve political conflict: powerful political interests are at stake in security sector reform because such a process - which features efforts to reverse the neo-patrimonial state by introducing more human security-centred governance - can threaten the existing distribution of power. Indigenous informal solidarities embedded into state structures, often based on kinship or ethnic solidarities, can

become the subject of power struggles between competing social groups and their leaders, and are utilised by those groups and leaders for their own benefit, regardless of the needs of the 'nation' or the 'citizenry'. In a way, the whole debate about neo- patrimonialism, clientelistic networks and patronage (...) revolves around this usurpation of imported formal governance structures by indigenous informal societal forces' (Boege et al. 2009).

Finally, this IDS Bulletin seeks to capture the role of political elites in the development of formal and informal security policies and the ways in which they influence the exercise of policing, power and representation at the local level. The most powerful political factions ensure that the administrative/bureaucratic apparatus operates in a way compatible with the requirements of the informal political order, which is a good illustration of Chabal's statement according to which, 'the success of the State [is] measured domestically, by both rulers and ruled, in terms of how well it performed according to the criteria relevant to the workings of the informal political sphere' (Chabal 2007). This IDS Bulletin is thus an invitation to pay attention to 'socially embedded forms of reciprocity' (Hyden 2006: 1). It shows that, even at the grassroots level, the traditional social obligations often are much more powerful than obligations as a 'citizen' or as a civil servant. In some cases, reform-minded national and international officers have to handle carefully the role of traditional authorities, particularly to take into account the influence of the powerful secret societies (such as the Bondo society) seen as 'guardians of culture as of community' (See Charley and M'Cormack, this IDS Bulletin); this requires a certain amount of knowledge of and familiarity with local customs and traditional authorities.

\section{Security from below: the role of traditional actors}

A growing number of security challenges are no longer confined to national borders, including: terrorism; drug, human beings and small arms trafficking; smuggling; plundering of natural resources; and illegal migrations. African states are all confronted by the same criminal transnational threats. The very classical responses mobilised by the state are not sufficient to address criminality. Today, some regions, in particular the Sahelian region is in fact experiencing a shift from conflict to transnational criminality. The distinction between external security on the one hand identified by a concern with mainly military threats coming from the aggressive behaviour of 
other states (and usually captured by strategic studies) and, on the other hand, internal security - identified as criminal, or otherwise disturbing activities, within the boundaries of a state (and traditionally captured by criminology or justice studies), has been increasingly blurred. This implies that both crime and war have tended to meet and, consequently, the role of the military and the police forces have increasingly coincided. The emergence of a growing number of transnational risks and threats challenge the traditional distinction between internal and external security in states ill-equipped to address them. Not being in a position to secure its borders and to mobilise significant human or economic resources, the African state proves unable to cope with transnational criminality. In this context, the role of informal security actors tied into networks of social relations and a web of mutual obligations - is increasingly important on the continent. Informal security in Africa is both embedded into economic (unequal development) and cultural (customs and traditions) structures. Although most African states claim authority within the boundaries of their internationally recognised territory, non-state institutions of governance which used to exist prior to the era of colonial rule have survived in large parts of that territory. In an important number of African countries, the state has proved unable to succeed in the centralisation and monopolisation of security. In much of Africa, there

has hardly [been]... any point in time [when the state] had a monopoly of legitimate force... [The] security sector has... typically manifested both formal and informal tracks. Even in states which are ostensibly stable, statutory institutions have been unable to provide security to all categories of its citizens at affordable levels, with supplementary roles being played by an array of traditional security actors... The Westphalian assumption that monopoly over the means of legitimate coercion lies with the state and its institutions meets a veritable challenge in the face of the wide support and legitimacy enjoyed by nonstate security institutions' (Ebo 2007: 10-11).

Such non-state institutions can be described as customary societal structures (extended families, clans, tribes, religious brotherhoods) and traditional authorities (village elders, religious leaders, headmen, clan chiefs, healers). Their influence is particularly important in rural and remote peripheral areas. As shown by Eric Scheye (2009: 5),

the post-colonial state is defined by the rule of the 'intermediaries', a series of networks and polities that substitute and compensate for the lack of authority of the central, legally constituted state and its ability to deliver essential public goods and services. In the postcolonial state, state agencies are not the primary vehicles for the distribution of public goods and services. Non-state systems and institutions which, together, effectively function as a 'second state' assume that role and function and they provide the preponderance of all public goods and services.

This IDS Bulletin shows how the traditional security providers are often seen by local communities as more effective and efficient than the state's ones but also as much more legitimate. Official procedures enforced by the states are often seen as hardly understandable or accessible. The way in which traditional security providers deliver security is congruent with norms and historical legacies of communities and populations who rely on their services. Our publication is in compliance with the burgeoning literature relating to such non-state security actors, which, if not prolific has been rich over the last few years (Kassimir 2001; Keulder 1998; Ayoade and Agbaje 1989; Jorgël and Utas 2007; Heald 2007). ${ }^{6}$ Bruce Baker has emphasised particularly well the importance of informal policing on the continent (Baker 2004a, b and 2008). Baker defines policing as 'any organised activity that seeks to ensure the maintenance of communal order, security and peace through elements of prevention, deterrence, investigation of breaches, and punishments. It is in fact a mechanism of governance. As such, it can be authorised and provided by non-state groups as well as the state' (Baker 2004b: 165). In Africa, there is an increasing diversification of policing away from state to non-state policing agencies: Baker seeks to understand the variety of policing existing in Africa. Illustrating Baker's concept of 'multi-choice policing', this IDS Bulletin puts the stress on an important number of policing agencies which are offering localised protection of different levels of legality, effectiveness, availability, methods and service, showing that African populations are confronted with a 
multiple-choice of private and public, legal and illegal, formal and informal policing (see also Baker and Scheye 2007).

\section{Re-formation and reinvention of customary practices}

It would be misleading, however, to see traditional and customary practices as unchangeable and static: far from frozen in past practices, the intervention of traditional and customary actors are in fact subject to re-formation and reinvention.

Firstly, the role of customary and traditional networks might be blurred more often than not. Indeed, criminal networks involved in drug trafficking, terrorist activism, etc. are in some cases embedded in traditional societal structures and tied back to kinship-based entities and common localities of origin. ${ }^{7}$ There is sometimes a convergence of interests between criminal networks and local communities.

Secondly, most criminal activities in Africa particularly in the Sahel - are not local in essence but are connected to regional and global criminal networks. ${ }^{8}$ As shown by Boege et al. the

combinations of forces from the customary sphere - like chiefs, traditional kings, religious authorities and their constituencies - and from the sphere of (...) new formations - like warlords and their militias, ethnic or millenarian movements or rackets of organised crime. The new formations are often linked to traditional societal entities and attempt to instrumentalise these for their own new goals, such as power and profit' (Boege et al. 2008: 9).

Via drug trafficking and terrorism, locally embedded orders link into the globalised market and global society. Criminal actors such as terrorist or drug traffickers can also provide protection, welfare services or sources of incomes to local communities.

Thirdly, there is a need to locate the informal security sector within the discourses of equitable security governance: there is a linkage between poverty and the role of traditional and customary communities in security. Scharf and Nina (2001) have rightly assumed that when the state does not adequately protect the poor, they tend to rely on informal security providers. This IDS Bulletin is in fact on the same page as Comfort Ero
(2000: 26), who sees vigilantes and local militias - such as the Kamajors (civil defence forces) of Sierra Leone - as cheap, community-based elements in search of security outside formal state structures.

Fourthly, customary processes and structures are subject to 'reinvention'. Traditional and customary institutions are undoubtedly showing a strong resilience; nevertheless they are subject to important changes and are exposed to external influences, being penetrated and informed both by the central state apparatus and by international norms. Increasingly, the states as well as the international actors are trying to incorporate traditional security mechanisms into their own strategies. New practices, not strictly customary but rooted in customs, are emerging: customary conflict management mechanisms can be combined with foreign as well as with statecentric approaches. A number of states have thus managed to control most of the informal and non-statutory groups, for instance, in Uganda, in Niger or in Togo (Hassane Boubacar 2010).

Malian national authorities have also been trying to incorporate the role of traditional and customs mechanisms, even if less formally than in other African countries. It is also important to mention the fact that a number of international actors, notably the Organisation for Economic Cooperation and Development (OECD) and the UK Department for International Development (DFID), are presently paying growing attention to the role of non-state/local actors. Indeed, some international donors are increasingly interested in customs and traditional mechanisms. DFID, in 2004, recognised the importance of non-state/local justice and security networks. The OECD followed suit in 2007 with an analysis of justice and security service delivery in fragile states:

The OECD has itself recognized the vitality of non-state/local justice and security networks, stating that 'a growing interest in and willingness to work with local institutions of governance - such as shuras in Afghanistan is also welcome. Traditional systems, which may not be recognisable in western states, may still perform the same functions and generate the same outputs as formal state institutions. Respect and willingness to accommodate such systems [...] can be helpful in restoring governance' (OECD-DAC 2008: 36). 
New networks, which are coming along on top of the traditional ones, are presently emerging. The 'alternative security concept' - which has been promoted in Northern Mali - is a telling example of the 'processes of assimilation, articulation, transformation and/or adoption in the context of the global/exogenous -

local/indigenous interface' (Boege et al. 2008: 7). This alternative security concept promoted by both international donors and traditional authorities is giving a sense of the process of syncretism between international norms and local conflict mechanisms at stake in security sector reform processes in Southern countries. The concept of 'alternative security' can clearly be seen as a combination of the two ideal types of community policing ${ }^{9}$ which have been identified by Wisler and Ihekwoaba:

Community policing 'Western style' is described as a top-down approach of security, with a [sic] police taking the lead in mobilizing community self-rule in policing matters. In many places in the world, but perhaps more researched and visible in Africa than elsewhere, community policing follows rather a bottom-up approach with communities initiating and practicing a great deal of informal, unofficial policing negotiated more or less successfully with the state. The first type, we argue, is a historical product of the Western nation state after the successful integration of peripheries and the development of a modern bureaucracy, while the second type is more likely in states with a weaker bureaucracy and a tradition of legal pluralism. In the latter context, rural and urban social movements alike might find in the tool box of culture robust informal policing practices to reproduce order and benefit from the support of powerful political allies (Wisler and Ihekwoaba 2007: 1).

The case studies of this IDS Bulletin present such a syncretism. The introduction of a community policing approach, heavily influenced and informed by the Western approach to the concept, has been promoted in most of the SSR processes studied here. However, the different environments have required different types of community engagement, involving traditional figures of authority as well as Civil Defence Forces, which had maintained law and order during recent wars. Traditional policing actors have not only provided their support to the reinstalment of the state security forces at the local level but also have cooperated with them and even been entrusted a number of duties (administration of civil justice in non-criminal cases; detention of prisoners in their own custodies once those have been prosecuted according to the law) (see Charley and M'Cormack, this IDS Bulletin).

\section{What is the research telling us?}

The contributions to this IDS Bulletin illustrate how the researchers involved in the Global Uncertainties Programme have arrived at the conclusions mentioned above. The first article situates security sector reform processes within the general framework of the African Peace and Security Architecture (APSA) which is presently being set up at the continental level. Olaf Bachmann's article shows that the African Union and African states are severely dependent on external support for security sector capacitybuilding as well as for operations. His article outlines the threats that the African Standby Force (ASF) is confronted with, due to the lack of political, conceptual, and financial ownership on the side of the recipients, who are also its main stakeholders. The result is at best an ambiguous partnership between donors and African stakeholders.

The second article of this issue proposes a methodology to capture empirically hybrid security orders. Niagalé Bagayoko suggests that the multilevel governance approach can provide a relevant framework to study the way in which domestic security governance in African countries is reshaped by the interactions of the heterogeneous norms, standards and procedures underlying international and domestic policing processes. This article advocates an approach which consists of expanding the agenda of the traditional multilevel governance approach (mainly focused on the European Union) in order to capture the sets of actors and procedures which have driven the security reform process in the Central African Republic. Mapping out the various levels of government at which decisions are made, this article seeks to capture the intermingling of domestic and international decision-making processes which increasingly overlap and interfere with each other in Southern countries. 
Thierry Nlandu Mayamba maps out and examines the roles and responsibilities of the various formal institutions and stakeholders involved in the management of the police forces in the Democratic Republic of Congo (DRG). All security services in the DRG possess a legal framework within which they must operate. However, his article shows that the security and police sector stakeholders in the DRC are linked together in a web of complex and dynamic systems, characterised by discrepancies between theory and practice. Far from working either in opposition to one another or in parallel, these systems intertwine more than they conflict, and there are significant overlaps and confusion with regard to the mandates of the existing institutions, structures and actors involved. The legal contradictions and loopholes identified in this article are often the result of dubious interpretations, or even deliberate misinterpretations of existing operational provisions underlying the functioning of security services.

Joseph P. Chris Charley and Freida Ibiduni M'Cormack consider the way in which police reform has been conducted in Sierra Leone. They present the historical, institutional and political environment of the Sierra Leonean police since the era of British colonial rule to the late 2000s. The changes which occurred during and since the 1990s civil war, as well as the pivotal role played by a generation of reform-minded officers and by a British inspector of police, are paid particular attention. The constraints faced by the reform agenda and the tactics which were used to address them - especially those aimed at mobilising traditional actors or customs - are then analysed.

In another contribution, Niagalé Bagayoko highlights the specificities which have to be taken into account when enacting a Security Sector Reform process in environments with different traditions and backgrounds. This article maps out and analyses how security institutions work in Francophone and Anglophone African countries and how the different actors (security providers as well as oversight actors) relate to each other. The issue at stake is to highlight the kind of institutional framework prevailing in the two sets of countries.

Finally, Kalilou Sidibé investigates the way in which Sahelian states address the intermingling of terrorist and criminal activities and the way in which they are overlapping with communitarian/traditional conflict dynamics. A particular focus is the situation in Northern Mali, which is facing a combination of three major security issues: the increasing presence of Islamist terrorist groups, especially $\mathrm{Al}$ Qaeda in the Islamic Maghreb (AQIM); the expansion of criminal networks (both international and domestic) and the recurrent Tuareg rebellion. The issue at stake in this article is to identify how Malian authorities are coping with those threats, taking into account both local dynamics (particularly the relations between the criminal groups and the local populations in the north) and international policies (particularly those emanating from the United States, France and the European Union).

All the articles reaffirm the importance of conducting any analysis of African security governance at multiple levels. They all converge to state that even when central security forces exist, these are weakly controlled from the centre as they often depend on local predation for their subsistence. In all the contributions, networks are also seen as central in explaining how all the different levels function: the central organisations are managed informally on the basis of ethnic networks, and most of the articles highlight the continuing importance of ethnicity in the legitimation of authority; that traditional authorities and informal local security systems depend on more localised versions of these same networks for their resources; and international actors also have networks, their value-systems being at cross purposes to both the centre and traditional/local.

Finally, the key question raised by this IDS

Bulletin is whether or not the concept of 'hybridity' can be more than an analytical one and become a guide for action. Indeed, it can be argued that 'hybridity' in its broadest sense could be a strategy for building effective security systems at this stage of African state development. The articles gathered here suggest that 'hybridity' can be seen as an efficient and effective method of providing security, not just as an analytical tool for explaining dysfunctions in the security systems. Implicitly, the authors draw the hypothesis that it might be stimulating to consider some networks as valuable checks and balances whose mobilisation can contribute to 
African security order. As Boege et al. (2008: 16) state, there is a need for

de-emphasizing weakness, fragility, failure and collapse, and focusing on hybridity, generative processes, innovative adaptation and ingenuity. This also entails perceiving community resilience and customary

\section{Notes}

1 In this article, the word 'formal' refers to codified institutions and the word 'informal' refers to non-codified institutions.

2 Since 2009, the 'Global Uncertainties Programme', led by the Institute of Development Studies (Sussex) under the lead of Professor David K. Leonard, has been financed by the Research Councils of the UK.

3 As shown by David K. Leonard, the historical and foundational social contract for most Africans is not between the state and individuals - as assumed by the classical social contract theorists, which most of the international community refers to -but is instead with communities. Cf. Volume 2 of this IDS Bulletin edited by Professor David K. Leonard (Issue 44 No 1, forthcoming January 2013). Furthermore, Leonard concludes that some of these exchanges are 'contractual' but that others are simply 'bargains', that is they are agreements which last only as long as they are mutually beneficial and have less obligation.

4 Such an approach has been adopted by Emmanuel Kwesi Aning who has thoroughly analysed the endemic process of militarisation which used to characterise the Ghanaian police service from 1960 to 1980 (Aning 2004, 2006).

5 The conclusions of this IDS Bulletin are in fact very similar to the conclusions of Alice Hills (1996) who has offered a thorough analysis of police forces in African countries by examining the nature, functions and capabilities of African police forces as well as an analysis of public order under various governments and police systems. Exploring the impact of steps toward liberalisation of policing systems in 1990 in Eritrea, Ethiopia, Namibia, Somalia, Uganda and Zaïre, Hills (2000) has emphasised the irrelevance of an institutions not so much as spoilers and problems, but as assets and sources of solutions that can be drawn upon in order to forge constructive relationships between communities and governments, and between customary and introduced political and social institutions.

analysis assessing African police forces in terms of their adherence to democratic criteria: according to her (2007), the police are in fact governed according to presidential preferences because of the relationships between Presidents and their chief police officers (Commissioners or Inspectors General). Under such circumstances, public accountability is in fact playing a negligible role. In this way, Hills herself confirms the continuing relevance of Potholm's (1969: 142) observation according to which the police enforce decisions taken by political authorities.

6 Heald (2007) has focused on the development and history of sungusunu organisations in Kenya. Sungusunu have developed out of an indigenous organisation to control theft and particularly cattle raiding, and operate under the authority of the district administration: norms of crime, trial and punishment distinct from those enforced by the national penal code have been developed. Distancing themselves from the police and the judiciary, the sungusunu have had far-reaching effects on security at the local level.

7 In the second volume of this IDS Bulletin, Professor David K. Leonard will show how Somalian warlord systems are embedded in the local societal structure of clans and tribes (Issue 44 No 1, forthcoming January 2013).

8 Such as the example of drug trafficking from Latin America, which is increasingly transiting via the Guinea Gulf, particularly via Guinea Bissau, before penetrating the European market.

9 For a donor-driven approach of community policing, see Groenwald and Peake (2004). According to those authors, a communitybased approach of policing is not only meant to deal with crime but to address citizens' security concerns. 


\section{References}

Anderson, D.M. and Killingray, D. (eds) (1992) Policing Decolonisation: Politics, Nationalism and the Police, Manchester: Manchester University Press

Anderson, D.M. and Killingray, D. (1991) Policing the Empire: Government, Authority and Control: 1830-1940, Manchester: Manchester University Press

Aning, E.K. (2006) 'An Overview of the Ghana Police Service', Journal of Security Sector Management 4.2, April

Aning, E.K. (2004) A Comparative Analysis of Security Sector Governance in West Africa: The Ghana Case, Bonn: Friedrich Ebert Stiftung, Africa Wide Security Project

Ayoade, J.A.A. and Agbaje, A.A.B. (1989) African Traditional Political Thought and Institutions, Lagos: Centre for Black and African Arts and Civilization

Baker, B. (2008) Multi-Choice Policing in Africa, Uppsala: Nordiska Afrikainstitutet

Baker, B. (2004a) 'Multi-Choice Policing in Africa: Is the Continent Following the South African Pattern?', Society in Transition 35.2: 204-23

Baker, B. (2004b) 'Protection from Crime: What is on Offer for Africans?', Journal of Contemporary Studies 22.2: 165-88

Baker, B. and Scheye, E. (2007) 'Multi-layered Justice and Security Delivery in Post-Conflict and Fragile States', Conflict, Security and Development 7.4

Boege, V. (2006) Traditional Approaches to Conflict Transformation - Potentials and Limits, Berghof Conflict Research, Berlin, www.berghofhandbook.net/documents/publications/boege_ handbook.pdf (accessed 18 April 2012)

Boege, V.; Brown, A.; Clements, K. and Nolan, A. (2009) 'On Hybrid Political Orders and Emerging States: What is Failing - States in the Global South or Research and Politics in the West?', in M. Fischer and B. Schmelzle (eds), Building Peace in the Absence of States: Challenging the Discourse of State Failure, Berghof Conflict Research, Series No 8, Berlin: Berghof Research Center

Boege, V.; Brown, A.; Clements, K. and Nolan, A. (2008) On Hybrid Political Orders and Emerging States: State Formation in the Context of Fragility, Berghof Conflict Research, Berlin: Berghof Research Center, www.berghof-handbook.net/ documents/publications/boege_etal_handbook .pdf (accessed 18 April 2012)

Brinkerhoff, D. and Goldsmith, A. (2002)
Clientelism, Patrimonialism and Democratic Governance: An Overview and Framework for Assessment and Planning, paper prepared for US Agency for International Development Office of Democracy and Governance, Cambridge, MA

Chabal, P. (2007) State and Governance: The Limits of Decentralisation, The Hague: SNV

(Netherlands Development Organisation), www.snvworld.org/en/Documents/Knowledge $\% 20$ Publications/SNV_series_01_Africa_State \%20_of\%20governance.pdf (accessed 18 April 2012)

Debiel, T. and Lambach, D. (2009) 'How StateBuilding Strategies Miss Local Realities', Peace Review 21.1: 22-8

Debiel, T. and Lambach, D. (no date) Hybrid Political Orders in Fragile Environments, Institute for Development and Peace (INEF), DuissburgEssen University, North Rhine-Westphalia

DFID (2004) Non-state Justice and Security Systems, London: UK Department for International Development

Ebo, A. (2007) 'Non-State Actors, Peace-Building and Security Governance in West Africa: Beyond Commercialisation', Journal of Peacebuilding and Development 3.2: 53-69

Ero, C. (2000) 'Vigilantes, Civil Defence Forces and Militia Groups: The Other Side of the Privatisation of Security in Africa', Conflict Trends, Durban: The African Centre for the Constructive Resolution of Disputes (ACCORD)

Groenwald, H. and Peake, G. (2004) Police Reform Though Community-Based Policing: Philosophy and Guidelines for Implementation, New York: International Peace Academy/Saferworld Hassane Boubacar (2010) 'Autorités Coutumières et Régulation des Conflits en Afrique de l'Ouest Francophone: Entre le Formel et le Formel', in Kossi Agokla, Niagalé Bagayoko and N'Diaye Boubacar, La Réforme des Systèmes de Sécurité et de Justice en Afrique Francophone, Paris: Organisation Internationale de la Francophonie (OIF)

Heald S. (2007) 'Controlling Crime and Corruption from Below: Sungusungu in Kenya', International Relations 21.2: 183-99

Hills A. (2007) 'Police Commissioners, Presidents and the Governance of Security', Journal of Modern African Studies 45.3: 403-23

Hills A. (2000) Policing Africa: Internal Security and the Limits of Liberalization, Boulder CO: Lynne Rienner Publishers 
Hills A. (1996) 'Towards a Critique of Policing and National Development in Africa', The Journal of Modern African Studies 34.2: 271-91

Hyden, G. (2008) Institutions, Power and Policy Outcomes in Africa, London: Africa Power and Politics Programme (APPP)

Hyden, G. (2006) 'Between State and Communities: Challenges to Redesign Governance in Africa', paper prepared for a Working Conference on Designing Constitutional Arrangements for Democratic Governance in Africa: Challenges and Possibilities, held at the Workshop in Political Theory and Policy Analysis, Indiana University Bloomington, 30-31 March

Institute for Development and Peace (2008) 'Panel 1: The Internal Dynamics of Hybrid Political Orders', Peacebuilding in Developing Countries: New Perspectives on Internal Dynamics and External Engagement, Institute for Development and Peace (INEF), DuissburgEssen University, North Rhine-Westphalia

Jorgël, M. and Utas, M. (2007) The Mano River Basin Area: Formal and Informal Security Providers in Liberia, Guinea and Sierra Leone, Stockholm: Swedish Defence Research Agency

Kassimir, R. (2001) 'Producing Local Politics: Governance, Representation and Non-State Organizations in Africa', in T. Callaghy, R. Kassimir and R. Latham (eds), Intervention and Transnationalism in Africa: Global-Local Networks of Power, Cambridge: Cambridge University Press

Keulder, C. (1998) Traditional Leaders and Local Government in Africa, Pretoria: Human Science Research Council

Lund, Christian (2006) 'Twilight Institutions: Public Authority and Local Politics in Africa', Development and Change 37.4: 684-705

March, J.G. and Olsen J.P. (2004) The Logic of Appropriateness, ARENA Working Paper WP04/09, Oslo: Center for European Studies, University of Oslo, www.sv.uio.no/arena/ english/research/publications/arenapublications/workingpapers/working-papers 2004/wp04_9.pdf (accessed 18 April 2012)
March, J.G.and Olsen J.P. (1989) Rediscovering Institutions: The Organizational Basis of Politics, New York: Free Press

OECD (2007) Enhancing the Delivery of Justice and Security in Fragile States, Paris: Organisation for Economic Co-operation and Development (OECD), www.oecd.org/dataoecd/27/13/ 38434642.pdf (accessed 18 April 2012)

OECD-DAC (2008) Concepts and Dilemmas of State Building in Fragile Situations. From Fragility to Resilience, OECD-DAC Discussion Paper, Paris: Organisation for Economic Cooperation and Development (OECD)

Potholm, C. (1969) 'The Multiple Roles of the Police as Seen in the African Context', Journal of Developing Areas 3: 139-58

Scharf, W. and Nina, D. (2001) The Other Law: Non-State Ordering in South Africa, Cape Town: Juta

Scheye, E. (2009) State-Provided Service, Contracting Out and Non-State Networks: Justice and Security as Public and Private Goods and Services, Paris: The International Network on Conflict and Fragility (INCAF), Organisation for Economic Co-operation and Development (OECD)

Schmidt, V.A. (2006) 'Give Peace a Chance: Reconciling the Four (not Three) New Institutionalisms', paper prepared for presentation for the National Meetings of the American Political Science Association, Philadelphia, PA, 31 August-1 September, http://sws 1.bu.edu/vschmidt/documents/ givepeaceachancefinal.pdf (accessed 18 April 2012)

Scott, Z. and Mcloughlin, C. (2012) 'Informal and Customary Political Systems', Topic Guide on Political Systems, Governance and Social Development Resource Centre, University of Birmingham, www.gsdrc.org/docs/open/ PoliticalSystems.pdf (accessed 18 April 2012)

Wisler, D. and Ihekwoaba, D.O. (eds) (2007) Plural Policing in Africa (WPS No 6 to 10), International Police Executive Symposium Working Paper Series, New York 